Cronfa - Swansea University Open Access Repository

This is an author produced version of a paper published in:

Shakespeare Bulletin

Cronfa URL for this paper:

http://cronfa.swan.ac.uk/Record/cronfa47972

\title{
Paper:
}

Price, E. (in press). 'Why was The Knight of the Burning Pestle Revived?'. Shakespeare Bulletin, 37(1), 47-66.

This item is brought to you by Swansea University. Any person downloading material is agreeing to abide by the terms of the repository licence. Copies of full text items may be used or reproduced in any format or medium, without prior permission for personal research or study, educational or non-commercial purposes only. The copyright for any work remains with the original author unless otherwise specified. The full-text must not be sold in any format or medium without the formal permission of the copyright holder.

Permission for multiple reproductions should be obtained from the original author.

Authors are personally responsible for adhering to copyright and publisher restrictions when uploading content to the repository. 


\section{Why was The Knight of the Burning Pestle Revived?}

EOIN PRICE

Swansea University

Francis Beaumont's The Knight of the Burning Pestle was a famous failure when it was first performed. Its failure has fascinated generations of critics. Jeremy Lopez has gone so far as to say that "failure is the basis of the play’s canonical identity” (Constructing 75). Walter Burre, the play’s printer, offered one explanation for its lack of success, blaming the 1607 Blackfriars audience who, he claimed, failed to understand its "privy mark of irony" (A2r), yet scholars have offered an ingenious array of other interpretations. John Doebler is among those who propose that Beaumont was insufficiently critical of the citizens he satirized, alienating the play's elite audience in the process (xii). Andrew Gurr argues just the opposite, suggesting that the play’s “elitist satire” offended many citizen playgoers who were in attendance (Shakespearean 102). Richard Rowland contends that the privileged audience may have been embarrassed by seeing plays they secretly enjoyed subjected to scorn (“(Gentle)men” 28). Resisting the citizen/elite binary opposition, Brent Whitted claims that Beaumont caused dissension by conflating "two different audience cultures ... the Inns of Court and Blackfriars” (127), while Tracey Hill suggests the root of the problem may be found in Beaumont's conflation of “civic and theatrical dimensions,” bringing city and theater together without understanding the relationship already in place (171). Some scholars have blamed the play’s shocking newness for its poor reception: for Lee Bliss, Beaumont was ahead of his time (36), for Philip Finkelpearl, he was hampered by an audience who struggled "to accept and comprehend the truly new" (82). Sheldon P. Zitner notes, tentatively, that the fault may lie with the performers rather than with the play, or the audience (38), but other 
critics have aimed directly at Beaumont himself. Joshua Smith argues that the play’s “unintelligible satiric aims” resulted in its failure (495).

What all these accounts share is a conviction that the play failed, but, as Lopez points out, Burre’s proclamation of failure should not be taken at face value (Constructing 75). The play may have been met with muted success, or with mixed reviews, rather than total confusion, or absolute disdain. One thing is certain, it is easier to market extremity than mediocrity: Burre, a specialist in the printing of failed plays (Lesser 52-80), may have found it more helpful to emphasize (even to overemphasize) the play's failure. The notion that the play had "a privy mark" does not really work if half of the audience get it. Paradoxically, the play is easier to recuperate if it is a complete disaster. Failure graces it with exceptionality. Part of the allure of The Knight of the Burning Pestle derives from the assumption that modernity has appreciated what early modernity did not. Perhaps this is a partial explanation for why the play’s supposed failure has generated critical inquiry while its seeming success, thirty years later, has received very little attention. In the 1630s, Queen Henrietta Maria’s Men performed The Knight of the Burning Pestle at the Cockpit and, in 1636, at St James's Palace. In 1635, the play was printed again, this time bearing none of the marks of failure that had so distinguished the first quarto publication. Bearing this in mind, this article aims to redress matters by attending to a now familiar play in an unfamiliar context. Situating The Knight of the Burning Pestle in relation to the known repertory history of the Cockpit, I argue that changing theatrical circumstances enabled Queen Henrietta's Men to have success with a play which was once marketed as a flop. The change in the play's reception was not the inevitable consequence of its inherent brilliance, however, but was in part the result of a complex set of theatrical and cultural factors. The relatively understudied history of the play’s success is bound up with the relatively understudied history of the playhouse at which it found that success. 
The comparative lack of scholarly interest in the revival of The Knight of the Burning Pestle is also partly an effect of the critical tendency to privilege first performances and first publications. But, as this article will show, reprints and revivals can offer vital new perspectives, shifting the theatrical landscape and providing audiences with new ways of engaging with old plays. In this case, the play’s shift from the Blackfriars to the Cockpit involves traversing a canonical boundary: the Blackfriars, which became the home of the King's Men, has received valuable critical attention, but the Cockpit, which has no such Shakespearean connection, has suffered in comparison. It has hardly helped that the Cockpit's glory days appear to have coincided with a period of dramatic history still often treated by critics as derivative and stale. As the essays in this special issue demonstrate, however, the Cockpit was an important venue for lively and inventive drama. More specifically, in this article, I argue that the revival of The Knight of the Burning Pestle was a potentially risky venture which made possible a range of effects. These could alter, in significant ways, the theatrical experiences of its audiences. My interest then, is not in why the play failed, but why it succeeded, and what acknowledging its success might do for our understanding of the play, its performers, and its playhouse.

Zachary Lesser is one of the few scholars to have reflected on the seeming success of the play's revival. Lesser floats the idea that the publication of the first quarto may have helped enable the play's later theatrical success (80). Perhaps this text encouraged Christopher Beeston— the theatrical entrepreneur who established the Cockpit and managed Queen Henrietta Maria’s Men— to take a chance on a revival, but this still leaves unanswered the question of how it came to be a success (if that is what it was) when it was once a failure (as scholars assume). Eleanor Collins provides a different line of inquiry, noting that The Knight of the Burning Pestle was performed alongside plays which it ostensibly satirizes. 
Collins claims that Beaumont's play only ridicules citizen values superficially and instead “works to realign audience tastes with the buoyant theatrical tradition of the amphitheatres". In this reading, the play was not (and perhaps could not be) successful in the repertory of the Children of the Queen's Revels with its prestigious Blackfriars fare, but made new sense in the repertory of Queen Henrietta Maria’s Men, at the amphitheater-play-accepting Cockpit. In this article, I want to expand upon, but also modify, Collins’s account. I do this first by considering the play in its earliest theatrical context. Next, I set the play in in the theatrical landscape of the 1630s. I then discuss a range of interpretive possibilities made available when Queen Henrietta Maria’s Men performed The Knight of the Burning Pestle. Finally, I examine what motivated Beeston to take a risk in staging a play previously marketed a failure, by placing Beaumont's play alongside other ostensible failures recuperated around the same time.

\section{The Knight of the Burning Pestle in 1607}

Although The Knight of the Burning Pestle may have failed when first performed, Lucy Munro rightly points out that, in many ways, the play’s delight in risky metatheater and generic experimentation is typical of the material staged by the Children of the Queen’s Revels (Children 1). Beaumont’s self-reflexive Induction has parallels with earlier Blackfriars drama. Several years before the premiere of Beaumont’s play, Ben Jonson’s Children of the Chapel Royal comedy, Cynthia's Revels (1600; Wiggins \#1269), opened with its own metatheatrical flourish, as three child actors argue over who should play the prologue, while John Day's The Isle of Gulls opens with three gallants discussing the name of the play they have come to watch and interacting with a bemused prologue. Indeed, Munro notes that plays like Thomas Middleton’s Your Five Gallants (1607; Wiggins \#1528), John Fletcher’s The Faithful Shepherdess (1608; Wiggins \#1582), and Beaumont and Fletcher’s The 
Coxcomb (1609; Wiggins \#1598) seem to have helped the Children of the Queen’s Revels forge a reputation for "experimental, iconoclastic” drama (Children 19). While scholars disagree about the purpose of satire in The Knight of the Burning Pestle, satire was clearly a strength of the company who performed it. John Marston’s The Malcontent (1603; Wiggins \#1391), The Dutch Courtesan (1604; Wiggins \#1434), and The Fawn (1605), Day’s Law Tricks (1604; Wiggins \#1436), George Chapman’s Monsieur D’Olive (1605), and Edward Sharpham's The Fleer (1606), all helped introduce a "harsher satiric strain” to the repertory (Munro Children 19). Munro further observes that the Jacobean preoccupation with prodigal young men, evident in Beaumont's play through the character of Jasper, manifests itself in the Children of the Queen's Revels repertory (Children 59). Chapman, Jonson, and Marston’s Eastward Ho! (1605), Middleton's A Trick to Catch the Old One (1605), and Beaumont and Fletcher’s The Scornful Lady (1610; Wiggins \#1626) also stage versions of comic prodigality.

Table A: New Children of the Queen's Revels plays, 1605-1607

$\begin{array}{llll}\text { Author(s) } & \text { Play Title } & \text { Date (Wiggins) } & \text { Wiggins \# } \\ \text { Marston } & \text { The Fawn } & 1605 & 1455 \\ \text { Chapman } & \text { The Widow's Tears } & 1605 & 1456 \\ \text { Middleton } & \text { A Trick to Catch the Old One } & 1605 & 1467 \\ \begin{array}{l}\text { Chapman } \\ \text { Chapman, Jonson, }\end{array} & \text { Monsieur D'Olive } & 1605 & 1468 \\ \begin{array}{l}\text { and Marston } \\ \text { Marston }\end{array} & 1605 & 1473 \\ \begin{array}{l}\text { Day } \\ \text { Sharpham }\end{array} & \text { The Wonder of Women (Sophonisba) } & 1605 & 1485 \\ \text { Middleton } & \text { The Isle of Gulls } & 1606 & 1491 \\ \text { Middleton } & \text { The Fleer } & 1606 & 1495 \\ \text { Beaumont and } & \text { 'The Viper and her Brood' } & 1606 & 1497 \\ \text { Fletcher } & \text { Your Five Gallants } & 1607 & 1528 \\ \text { Beaumont } & \text { Cupid's Revenge } & 1607 & 1533 \\ & \text { The Knight of the Burning Pestle } & 1607 & 1562\end{array}$

Table A lists an example of new plays staged by the Children of the Queen’s Revels in the years before the first performance of The Knight of the Burning Pestle. Some, if not all these plays, were performed alongside Beaumont’s play in 1607. The list includes several 
tragedies which make radical revisions to generic expectation. Middleton’s “The Viper and her Brood” is lost, but Sophonisba and Cupid's Revenge both bend or blur the boundaries of tragedy. Lopez observes that Sophonisba employs the contrasting conventions of “melodramatic, classically-informed tragedy” and “Jacobean revenge drama,” making each look at different times "both plausible and ridiculous” (Theatrical 157). Rebecca Yearling concurs, adding that, like other Marston plays, Sophonisba appears to accord with, but then ultimately undercuts, established dramatic and generic expectations (121). Cupid's Revenge mixes genres iconoclastically, combining revenge tragedy with pastoral romance and tragicomedy (Munro Children 117); Claire R. Kinney reads the same play as a "comi-tragedy" which adapts, reimagines, and resists Sir Philip Sidney’s Arcadia by blurring generic expectations (124). The Knight of the Burning Pestle displays irreverence towards supposedly widely-held ideas about tragedy, sending up established tragic hits like The Spanish Tragedy (1587; Wiggins \#783); this kind of generic game-playing was, then, in keeping with the Queen’s Revel's tragedies, as well as its comedies. The Knight of the Burning Pestle looks like it fits well within the wider repertory, even if it was not well-received by its first audience.

But The Knight of the Burning Pestle should not be viewed only in relation to its repertory stablemates. Indeed, scholars usually take the play's principal satiric focus to be the drama staged by adult companies at outdoor playhouses. In her study of Queen Anna’s Men and the Red Bull, Eva Griffith notes: "Any critic who misses the fact that the majority of the dramas satirised are early Heywood/Worcester's/Queen’s Servants plays [...] misses a vital component of the audience amusement attempted” (211). Beaumont's singing Merrythought parodies Valerius in Thomas Heywood's Queen Anna’s Men play The Rape of Lucrece (1607; Wiggins \#1558), while Beaumont also alludes to Heywood’s The Four Prentices of London (1602; Wiggins \#1351), 2 If You Know Not Me, You Know Nobody (1604; Wiggins \#1433), 
and The Travels of the Three English Brothers (1607; Wiggins \#1534) by George Wilkins, John Day, and William Rowley. ${ }^{1}$ Beaumont's reference to Jane Shore (Induction, 51) may refer to Heywood's two Edward IV plays (1599; Wiggins \#1195 and \#1196) or perhaps to the anonymous ‘Shore’ (1604; Wiggins \#1424) which, Wiggins posits, may have been performed by Queen Anna’s company. The Induction also refers to a now lost play, possibly by Heywood (Induction, 53), called “The Bold Beauchamps” (1605; Wiggins \#1471). ${ }^{2}$ Scholars have made important qualifications to older accounts which typically presented these plays, their performers, and their audiences as unsophisticated. ${ }^{3}$ However, it is nonetheless clear that the plays performed by Queen Anna's Men around the time The Knight of the Burning Pestle was written were different to the plays performed by the Children of the Queen's Revels in their styles and preoccupations. ${ }^{4}$

But while the relationship between The Knight of the Burning Pestle and the plays of Heywood and Queen Anna's Men is an important factor, Beaumont’s intertheatricality brings into play a much wider range of drama from across several distinct repertories. Martin Wiggins notes further verbal allusions to Thomas Kyd’s The Spanish Tragedy (1587; Wiggins \#783), Marlowe’s Edward II (1592; Wiggins \#927), Thomas Nashe’s Summer’s Last Will and Testament (1592; Wiggins \#941), Shakespeare’s Richard III (1595; Wiggins \#950) and 1 Henry IV (1597; Wiggins \#1059). He also notes direct references to Mucedorus (1591; Wiggins \#884) and “Nineveh,” a lost puppet show (1599; Wiggins \#1210). Editors have identified numerous other parodic allusions to plays by a range of different companies. Andrew Gurr notes that when Merrythought gives Jasper ten shillings, he parodies the opening scene of Thomas Dekker’s Old Fortunatus (1599; Wiggins \#1217); Michael Hattaway reads Jasper's emergence from the coffin (4.277) as an allusion to Lording Barry’s The Family of Love (1607; Wiggins \#1529), Jasper’s speech about “ghastly looks” (5.20) as an echo of Macbeth (1606; Wiggins \#1496), and Rafe’s forked arrow incident (5.283) as a 
parody of 3 Henry VI (1592; Wiggins \#919), while Zitner (117) suggests Nell’s demand that Rafe should “Kill, kill, kill, kill, kill” (3.349) may recall King Lear (1605; Wiggins \#1486).

William N. West has outlined a theory of intertheatricality in which plays are "a reverberant constellation of speeches, gestures, and interactions” (152); this useful definition can help attest to the complexity of moments like Rafe's death speech (5.284-319) which, as Hattaway notes, channels ghost scenes from The Spanish Tragedy and Richard III but also comic parodies like Eastward Ho! The full sum of the play’s many and varied allusions can never be recovered, and critics have inevitably tended to spot references to well-known plays (especially plays by Shakespeare), but Beaumont evidently cast his net widely, alluding to older plays like Mucedorus and 3 Henry VI as well as very new plays like Macbeth, The Rape of Lucrece and The Family of Love. Queen Anna's Men come in for sustained satire, but so too do plays by other companies, including those performed by the King's Men. Although West's point about intertheatricality applies broadly to the plays of the early modern period, The Knight of the Burning Pestle is peculiarly aware of its own place in the theatrical landscape of 1607. Despite (or perhaps because of) this awareness, the play seems to have failed to please its audience, but several decades later, it found some success.

\section{The Knight of the Burning Pestle in the 1630s}

In 1635, Nicholas Okes, the printer of the first edition of The Knight of the Burning Pestle, printed another edition of the play, this time for “I.S.” Whereas Burre’s first edition famously described the play as a theatrical failure and withheld performance details from its title page, the 1635 quarto announced that the play was printed “As it is now Acted by Her Majesties Servants at the Private house in Drury Lane. 1635.” The second edition does away with Burre’s defensive epistle, replacing it instead with an address “To the Readers of this Comedie” which, while not referring explicitly to performance, does not try to disavow the 
play's theatrical appeal, instead offering a defense of the play's satire on behalf of the long since deceased Beaumont: "the Author had no intent to wrong any one in this Comedy, but as a merry passage, here and there interlaced it with delight, which hee hopes will please all, and be hurtful to none” $\left(A 3^{r}\right)$. The edition also contains a lightly-amended prologue taken from John Lyly’s Sappho and Phao (1584; Wiggins \#753). David Bergeron suggests that the impulse to include this prologue among the paratextual material may have been "textual rather than theatrical” (464) and that the 1632 collection of Lyly plays Six Court Comedies often Presented and Acted before Elizabeth may have caught the eye of the publisher. But whatever the reason for the inclusion of the Lyly prologue, it is clear that the edition is keen to draw upon the cachet of the Queen Henrietta Maria’s Men revival and to emphasize theatrical success in a way dissimilar to the earlier occasion.

The title page declaration that the play is "now Acted" suggests that The Knight of the Burning Pestle was in the company repertory in 1635, but it is unclear exactly when Beeston acquired the play. The possibility that it was revived some years before the publication of the second edition cannot be ruled out, although, as I will discuss later, the 1630s may have been an especially good moment to acquire it. The title page says nothing about whether the play was well received by its audience, but the decision not to market it as a failure, coupled with the fact that it was performed at court at St James's Palace on 28 February 1636 (Steele 257) suggests it was a success. ${ }^{5}$ Indeed, although Queen Henrietta Maria’s Men split and reformed at the Salisbury Court playhouse later in the decade, Beeston retained the play in the repertory of the King and Queen’s Young Company (also known as Beeston’s Boys) who performed at the Cockpit. According to Wiggins (\#1562), The Knight of the Burning Pestle was also performed by amateur actors at Skipton Castle some time between 18 February and 12 July, perhaps attesting to a further renewal of theatrical interest in this once maligned play. These further revivals and their different theatrical contexts are worthy of additional 
investigation, but for the purpose of this essay I will limit my attention to the first revival, by Queen Henrietta Maria’s Men.

As Table B shows, the repertory of Queen Henrietta Maria’s Men differed greatly from the repertory of the Children of the Queen's Revels. The table documents examples of plays known to have been performed in the first half of the 1630s; it is not an exhaustive list but gives an impression of the available repertory. Perhaps most intriguingly, the company revived former Red Bull plays including Heywood's 1 If You Know Not Me, You Know Nobody (which Heywood updated for a Caroline performance), The Fair Maid of the West, and The Rape of Lucrece (which was updated with additional songs), around the time that they also revived The Knight of the Burning Pestle. It is not clear how well a 1607 Blackfriars audience would know (or enjoy) the plays of the Red Bull, but a 1630s Cockpit theatergoer would presumably know (and perhaps, we might infer, enjoy) both The Knight of the Burning Pestle and the Red Bull plays it pokes fun at. The company also revived Elizabethan tragedies like Marlowe's The Jew of Malta, which was over forty years old when it was first printed in 1633, bearing the marks of a recent Cockpit revival. The Knight of the Burning Pestle parodies some of the conventions of what was, even by 1607, an older style of tragedy, quite distinct from the Queen’s Revels’ generically unusual or dangerously topical tragedies like Cupid’s Revenge or Chapman’s Byron plays (1608; Wiggins \#1575 and \#1576). The fact that Queen Henrietta Maria’s Men performed older Elizabethan tragedies alongside The Knight of the Burning Pestle may have further enhanced an audience's enjoyment of Beaumont's tragic parody.

Table B: Plays in Queen Henrietta Maria’s Men repertory c.1630-1635

$\begin{array}{llll}\text { Author(s) } & \text { Play Title } & \begin{array}{l}\text { Date first } \\ \text { performed } \\ \text { (Wiggins) }\end{array} & \text { Wiggins \# } \\ \text { Christopher } & \text { The Jew of Malta } & 1589 & 828\end{array}$


Marlowe

Henry Chettle $\quad$ The Tragedy of Hoffman $1603 \quad 1384$

$\begin{array}{lll}\text { Heywood } & \text { The Rape of Lucrece } & 1607\end{array}$

Heywood If You Know Not Me, You Know Nobody 1604

$\begin{array}{lll}\text { Beaumont } & \text { The Knight of the Burning Pestle } & 1607\end{array}$

$\begin{array}{lll}\text { Heywood } & \text { The Fair Maid of the West } & 1610\end{array}$

Ford, Dekker, and The Witch of Edmonton 1621

Rowley

$\begin{array}{lll}\text { Middleton and } & \text { The Changeling } & 1622\end{array}$

Rowley

Heywood

John Ford

James Shirley

Joseph Rutter

Thomas Nabbes

Heywood

2 The Fair Maid of the West 1630

2320

'Tis Pity She's a Whore 1631

Hyde Park $1632 \quad 2367$

The Shepherd's Holiday $1633 \quad 2402$

Covent Garden $1634 \quad 2424$

Love’s Mistress $1634 \quad 2451$

In addition to staging older Elizabethan tragedies and plays once associated with the Red Bull,

Queen Henrietta Maria’s Men produced and performed new material, which had the potential to inform their revival of The Knight of the Burning Pestle. John Ford's 'Tis Pity She's a Whore draws on Elizabethan and Jacobean tropes, so may have complemented the revived tragedies by Marlowe and Chettle and in turn enhanced the humor of some of Beaumont's tragic parodying. James Shirley’s Hyde Park and Thomas Nabbes’s Covent Garden, which both participated in a Caroline vogue for topical city comedy, may have helped give The Knight of the Burning Pestle, which contains elements of city comedy, an additional comic charge. Indeed, Hyde Park has a note of what Adam Zucker terms “exotic tragicomedy” (172) when Master Bonavent claims to have been held hostage by a Turkish pirate. This curious, playful moment, potentially incongruous for a London-based comedy, may have been Shirley's way of nodding his head to the fanciful tales of adventurer plays like The Fair Maid of the West and its sequel, with which his play was in repertory. This kind of intertheatrical allusion is, of course, in line with what Beaumont attempts in The Knight of the Burning Pestle. Additional playful parallels are likely, as I will later discuss. 
At the other end of the spectrum from the older, nostalgic plays, Joseph Rutter's The Shepherd's Holiday and Heywood's Love's Mistress, or the Queen's Masque attest to the company’s eagerness to appeal explicitly to a courtly audience. When Rutter's play was printed in 1635 it was advertised as a "PASTORALL TRAGI-COMAEDIE” which had been “ACTED BEFORE BOTH THEIR MAIESTIES AT WHITE-HALL,” while the title page of the 1636 first edition of Heywood's play proudly advertised itself as “three times presented before their two Excellent MAIESTIES, within the space of eight dayes; In the presence of sundry Forraigne AMBASSADORS.” These plays were fashionable, aiming to address the interests of their royal patron; they offer a reminder that the company was keen to look forwards, towards the latest theatrical trends, as well as backwards, towards the nostalgic past which is so often taken to be characteristic of Caroline drama (Butler 181-85). In their generic adventurousness, these plays find a kinfolk in The Knight of the Burning Pestle. Moreover, in its “insistent metatheatricality” (Coffin 227), Love’s Mistress shares further similarities with Beaumont’s play. Collins notes: “Like Midas in Love’s Mistress, the definitively 'low' citizen couple and apprentice of The Knight of the Burning Pestle intervene in and re-interpret the action of the play according to their own preferences during the performance.” ${ }^{6}$ There are other affinities too: the vexed social politics of Beaumont’s play has caused critical consternation, but while Love's Mistress has received comparatively little attention, scholars who have studied the play invariably discuss its curious handling of supposedly elite and popular material. ${ }^{7}$ In their different ways, Beaumont and Heywood broached issues of theatrical taste, troubling received expectation. In this regard, the two plays, old and new alike, fit well within a diverse repertory comprising old hits from the outdoor playhouses and new plays, made for the Cockpit, and the court.

\section{Reading revival}


So far, I have argued that The Knight of the Burning Pestle was a good fit for its repertory when it was first performed, where it was played alongside experimental, metatheatrical satires, and when it was revived, where it was staged alongside the plays it satirizes, as well as new plays which shared similar preoccupations. These arguments are perhaps the inevitable consequence of a repertory approach; after all, the logic of repertory studies holds that plays were performed together for a reason. Repertories are not accidental, they are carefully created by professionals whose livelihoods rest on their success. However, proponents of repertory studies have acknowledged that the approach has limitations. ${ }^{8}$ For example, in attempting to identify repertorial characteristics, scholars risk making the plays in a repertory sound too similar to each other; by the same token, scholars also risk occluding potential connections between different companies. It is surely true that a play's repertorial context can generate new readings and possibilities, but it is presumably also true that it might not. Not all audience members will necessarily share the same sense of a company’s supposed identity, nor will they be equally familiar with the plays being performed. In what follows, I attempt to discuss some of the ways in which the revival of The Knight of the Burning Pestle might make possible meanings which were not available (or much less readily available) when it was first performed. My account privileges the changing theatrical and cultural circumstances, but some audience members at the Cockpit in the 1630s may have enjoyed the play without thinking much about the factors I consider to be important. There will have been many ways to enjoy The Knight of the Burning Pestle in the 1630s, no doubt far more than I will be able to attest to, but since scholarship has overwhelmingly focused on how the play failed it is important to think about some of the ways in which it may have succeeded.

When The Knight of the Burning Pestle was revived, it was nearly thirty years old: a play that may have once seemed shockingly new was now old. Queen Anna’s Men continued 
to produce citizen-centered romances after the first performance of Beaumont's play, and at least some of these plays transferred to Queen Henrietta Maria’s Men and the Cockpit, while the company also commissioned new plays which continued this tradition. These included 2 The Fair Maid of the West and John Kirke's The Seven Champions of Christendom (1634; Wiggins \#2432). Given that the play’s supposed initial failure is often blamed on its radical originality, it seems logical to argue that by the 1630s the audience had simply caught up with Beaumont’s invention. Alexander Leggatt suggests that there was no “discursive community” for The Knight of the Burning Pestle in 1607 but that such a community existed at the Cockpit by the time the play was revived (313). Perhaps so, but would the play have felt old to its Cockpit audience? So far as we can tell, it was not revived after its first run at the Blackfriars, so when it was performed at the Cockpit in the Caroline era it may have felt like a fresh, new play. Many of the plays in the repertory were established hits which could be reliably performed on a regular basis. The Knight of the Burning Pestle, however, was a new addition, which does not seem to have had a long performance history behind it. There is no guarantee that the audiences at the Cockpit necessarily knew that it was an old play when they went to see it performed.

Rather than viewing the 1630s revival as the performance of an old play whose theatrical invention was no longer shocking, I want to suggest that, in the context of the repertory of Queen Henrietta Maria’s Men, The Knight of the Burning Pestle became more boldly and transgressively inventive. In her discussion of the play’s “mind-bending uses of place” (69), Leslie Thomson shows how Beaumont "blur[s] the lines among players, characters, and playgoers” (61). The metatheatrical opportunities occasioned by a performance of The Knight of the Burning Pestle were arguably even greater in the 1630s. For example, if Martin Wiggins is right in his conjecture that the lost Ford play “The London Merchant” (1634; Wiggins \#2427) was performed around 1634, then this would further 
enhance the already extraordinary metatheatricality of Beaumont's play, in which the citizens, George and Nell, interrupt the scheduled performance of a play by that name. ${ }^{9}$ Wiggins makes an intriguing case for the play at the Cockpit, pointing out that it may have complemented Shirley's city comedies which were commissioned around the same time. He also notes the potential overlap with the revival of The Knight of the Burning Pestle but seems to suggest that the two were unlikely to have been performed together. Ford's play, he says, "might be more appropriately placed in 1634 than in the year when the same company revived The Knight of the Burning Pestle.” But Ford’s “The London Merchant” may have added pleasurable layers of comic complexity to the performance of Beaumont's play. Perhaps the audience were tricked into thinking that they might be watching Ford's play only to then realize they were watching Beaumont's. If this is right, the spatial gameplaying, genre-bending, and blurring of the real and the theatrical which critics take as characteristic of the play and its first performers would have been more pronounced and complex when staged at the Cockpit.

Beaumont's metatheatricality may have been enhanced in other ways too. Scholars have noted Beaumont's verbal parodying of Elizabethan plays like The Spanish Tragedy and Richard III (5.284-319), but West's concept of intertheatricality reminds us that allusion is often attained by non-verbal means. Writing of the 2014 Sam Wanamaker Playhouse production of The Knight of the Burning Pestle, Will Tosh observes that the director, Adele Thomas, deliberately engaged with and challenged audience expectations in the opening moments of her production. Aiming “to quote but then comically 'undo' many of the conventions established by [The Duchess of] Malfi," which was performed in the same season, Thomas had her actors burlesque the "graceful lighting of the candles" at the start of the Malfi production (115). Similarly, Queen Henrietta Maria’s Men may have played with the expectations of their audience by visually quoting tragedies in their own repertory. By the 
mid-1630s the company had performed or were performing John Webster's The White Devil (1612; \#1689), 'Tis Pity She's a Whore, and The Changeling. The Children of the Queen's Revels had their own tragedies to burlesque, but they had fewer of them, and their generic experimentation makes them less suitable for the kind of quotation Thomas attempted in her production. The tragedies in the Cockpit repertory also mix the tragic and the comic, but they are perhaps more likely to register as tragic than a play like Cupid's Revenge which in turn means they are easier to parody. The comical citation of these plays may be more pronounced when the quoter and the quoted are in closer proximity, as they were at the Cockpit.

Unlike in 1607, the actors who performed in the revival of The Knight of the Burning Pestle also performed roles in some of the plays which it satirizes. George’s malapropism “'Rafe and Lucrece’” (Interlude 2.14) would have an extra metatheatrical dimension, given that the actor playing Rafe will have performed in The Rape of Lucrece himself (he may even have played Lucrece). The intertheatrical connections with Heywood's play may have been especially strong: the actor who played the role of the singing clown, Valerius, would have been a good choice to have played Merrythought. This casting decision might allow for an even more complex audience engagement. A randomly-selected audience member at the Cockpit is likely to have seen The Rape of Lucrece, perhaps even multiple times, but it is less clear that a 1607 Blackfriars audience member would be as well acquainted with the play; likewise, it is not clear how well a 1607 audience member at the Red Bull would know The Knight of the Burning Pestle. By situating the plays within the same repertory, Queen Henrietta Maria’s Men make it easier for the audience to see them as mutually informative. An audience watching Merrythought is likely to think of Valerius, and vice versa, especially if the role is played by the same actor. Although Beaumont may never have thought about whether his play would enrich or complicate an audience's enjoyment of The Rape of Lucrece before he died in 1616, Beeston and Queen Henrietta Maria’s Men presumably did 
when they were in receipt of the play. Scholars have addressed the disturbing generic queasiness of Valerius’s incongruous songs: Lopez, for example, argues that Valerius’s clownish singing creates "generic confusion, where comedy and tragedy seem to speak at the same time” (Constructing 152). ${ }^{10}$ If the audience is thinking of dear old Merrythought when they are listening to Valerius, then their experience may be even more disturbing and generically bewildering. Although The Knight of the Burning Pestle and The Rape of Lucrece were both old plays in the 1630s, they will have found new ways to mean new things to new audiences.

So far, I have focused largely on the ways in which The Knight of the Burning Pestle may have seemed more extraordinarily inventive in the 1630s than it did in 1607, but it is worth reflecting on the possibility that some of its satiric power may have dissipated. As we have seen, scholars rarely agree about Beaumont's satiric intentions or the effect of his satire upon his earliest audiences. It is hard to say how differently The Knight of the Burning Pestle may have been perceived in the 1630s when there is so little consensus about how it worked in 1607. But the relocation of the play to the Cockpit and the repertory of Queen Henrietta Maria’s Men seemingly reoriented the direction of the play’s satire. In 1607, The Knight of the Burning Pestle parodied a theatrical style which was very different from its own and from that of its repertory companions; in the 1630s, it alluded to plays in repertory performed alongside it and to a style which was congruent with some of the preoccupations of the company and its audiences. The satirical charge attempted in the earliest performances of The Knight of the Burning Pestle comes not merely from the idea of audience interruption, but from a particular kind of audience member demanding a play that the company could not perform. At the Cockpit, this joke would work differently; arguably, it may lose some of its satirical edge. Indeed, Robert Zacharais’s argument that the script of the play allows Rafe to be "played 'straight,' as the smartest character on the stage with a true passion for drama and 
a serious grudge against the social structures under which he must serve” (121), while perhaps overstated, looks more enticing in the context of a repertory which contained If You Know Not Me, You Know Nobody and the two parts of The Fair Maid of the West.

But although some parodic or satiric aspects of the performance may have been toned down, it may be more accurate to suggest that the direction of the satire shifts, rather than disappears. As we have seen, The Knight of the Burning Pestle has multiple satiric targets. As well as alluding to the plays of what was then Queen Anna’s Men, it also refers to and parodies plays from a variety of companies. Most of these parodic references are to plays by companies other than their own. When performed by Queen Henrietta Maria’s Men, the play would presumably have felt more self-parodic. Whereas the Children of the Queen's Revels performance seems largely to have made other people the butt of the jokes, the 1630s performers would have been joking about their own plays. Self-parody, then, is likely to have formed a part of the revival's arsenal of theatrical tricks. But the revival may have given The Knight of the Burning Pestle new satirical sparks. The Cockpit playhouse was the principal rival to the King’s Men’s Blackfriars. This rivalry intensified in the early 1630s (Rowland 2010, 334-40). Angry at the poor reception of his Blackfriars play The Just Italian (1629; Wiggins \#2282) coupled with the positive response received by James Shirley’s The Grateful Servant (1630; Wiggins \#2287) at the Cockpit, William Davenant and his associates attacked the Cockpit and its audience. The 1630 edition of The Just Italian contains an epistle by Thomas Carew attacking both the Cockpit and the Red Bull as "adulterate” stages (A4"). The acrimony from jibes like this and the responses they engendered seems to have died down by the mid part of the decade (indeed, by the start of the 1640s, Davenant was working with Beeston's Boys at the Cockpit), but the episode demonstrates that the rivalry between the two theaters could have an edge. In this context, Beaumont's parodies of plays by Shakespeare and the King's Men may have had an extra satiric charge. 
Ultimately, the performance details and the audience reception of the 1630 s revival remain as elusive and contentious as the details of the 1607 first performance. They also remain much less studied. This article has offered some ways of thinking about the effects of the revival of The Knight of the Burning Pestle and the practice of revival more broadly. It has argued that the changing theatrical circumstances enabled the play to work in new ways as the company who performed it seized upon opportunities to draw out some of its best qualities. Although the critical orthodoxy is to privilege first performances over revivals, in some cases revivals will be more successful, richer, or more complex than the originals. I propose that The Knight of the Burning Pestle may be one such case.

\section{Coda: Christopher Beeston and theatrical risk}

The title of this article poses a question: why was The Knight of the Burning Pestle revived? The revival's apparent success provides one answer. Beeston's job, as the manager of Queen Henrietta Maria’s Men and the proprietor of the Cockpit, was to ensure that his ventures were a financial success. The best way to do this was to produce or acquire plays capable of pleasing audiences. I have argued that The Knight of the Burning Pestle interacts well within the wider repertory of Queen Henrietta Maria’s Men; Beeston, a canny operator, was well placed to see the potential connections with the plays he already had at his disposal. He is unlikely to have made the decision in a vacuum: as Collins argues, Heywood was acutely sensitive to, and deeply invested in, the company's repertory, adapting his own and other plays for revival while writing new ones. He may have relished the company's attempt to appropriate a play which displays such a strong interest in his dramatic output. The performance of The Knight of the Burning Pestle may have acted as an advertisement for his plays and as an opportunity for him to write new material that could interact with Beaumont's in productive ways. It may be that he had already written Love's Mistress by the time the 
company acquired The Knight of the Burning Pestle, but as the date of acquisition is unclear, the possibility that Heywood was thinking about Beaumont cannot be ruled out.

In several respects, then, the play may have appeared very attractive, but as a reputed theatrical failure it surely also carried a risk. The play might have flopped again or, worse still, it could have offended his clientele. But Beeston, it seems, was happy to take some risks. Indeed, he had form when it came to reviving reputed failures. By 1631 the company was performing The White Devil, a play which Webster himself recorded as a flop when it was first staged by Queen Anna’s Men in 1612. Perhaps Beeston thought that the indoor Cockpit would be a better venue for the play than the "open and blacke" theater Webster bemoaned in his preface to the first edition (A2 $)$. Perhaps he simply thought it was a good play, worth another shot. Whatever his reasons, he took the risk and it seems to have paid off, or at least it did not discourage him from taking further risks. Beeston would have watched the success the King's Men had reviving The Faithful Shepherdess with curiosity (and possibly even envy). Fletcher's play was almost directly contemporaneous with the original production of The Knight of the Burning Pestle and it apparently had a similar reception. It was also marketed as a failure when it was first printed, around 1610. In 1634, however, it was printed with a new title page declaring the play's newfound success with the King's Men at the Blackfriars and at Somerset House. Fletcher's play was probably a safer bet than The Knight of the Burning Pestle as it catered to the same taste for pastoral tragicomedy that Queen Henrietta Maria’s Men tried to exploit with The Shepherd's Holiday around the same time. Even so, its successful recuperation may have given Beeston confidence or, if he was feeling especially pugilistic, it may have prompted him to outdo his rivals with an even more daring revival. The decision he and his company made apparently worked, which is testament, perhaps, to the enduring quality of the play. But it also shows the acumen of Beeston and Queen Henrietta Maria’s Men, who staged The Knight of the Burning Pestle as part of an 
enterprising repertory which mixed novelty and nostalgia. The performers and their playhouse deserve a greater share of critical attention; the role they played in the recuperation of this now canonical play is another reason to give it to them.

\section{Notes}

${ }^{1}$ For the relevant passages see 4.49-50, Induction.21-22, and 4.29-30. For discussion of the Heywood reference, see Connolly, 218. For discussion of The Travels of the Three English Brothers allusion, see Publicover, 700.

${ }^{2}$ For the relevant references see Induction.50-54. On "The Bold Beauchamps" see also the Lost Plays Database entry by Misha Teramura:

https://www.lostplays.org/index.php?title=Bold_Beauchamps [accessed 26 February 2018].

${ }^{3}$ For accounts that revise older assumptions about the Red Bull see Griffith, Munro (“Governing”), Lancashire, Astington, Straznicky, Bayer, and Loughnane. On Heywood, see Rowland (Thomas Heywood's).

${ }^{4}$ On the style of Jacobean boy companies, see Mary Bly; on plays performed at the Red Bull see Bayer (148-77).

${ }^{5}$ Playbook title pages sometimes make a point of publicising the theatrical reception of the plays they advertise — consider, for example, the 1633 title page of John Ford's Queen Henrietta Maria’s Men play Love’s Sacrifice (1632; Wiggins \#2360) which claimed to be 'RECEIUED GENERALLY WELL' — but most title pages eschew this kind of detail.

${ }^{6}$ Collins, forthcoming.

${ }^{7}$ See, for example, Rowland (2010, 232-97), Coffin (216-18), Price (63-64).

${ }^{8}$ For some useful caveats about repertory studies, see Craig and Greatley-Hirsch (199). 
${ }^{9}$ Wiggins offers a date range of $1619-1640$ but lists 1634 as his best guess. He contests the 1624 dating offered in the Annals of English Drama, arguing that this dating wrongly identifies the play with Ford and Thomas Dekker’s The Bristol Merchant (1624; Wiggins \#2142).

${ }^{10}$ See also Bretz and Lucas (66-67).

\section{Works Cited}

Astington, John H. "Playing the Man: Acting at the Red Bull and the Fortune.” Early Theater vol. 9, number 2, 2006, pp. 130-43.

Bayer, Mark. Theater, Community, and Civic Engagement in Jacobean London. U of Iowa P. 2011.

Beaumont, Francis. The Knight of the Burning Pestle. London. 1613. The Knight of the Burning Pestle. London. 1635.

Bergeron, David M. "Paratexts in Francis Beaumont’s The Knight of the Burning Pestle.” Studies in Philology, vol. 106, no. 4, 2009, pp. 456-67.

Bliss, Lee. Francis Beaumont. Twayne. 1987.

Bly, Mary. “The Boy Companies, 1599-1613.” The Oxford Handbook of Early Modern Theater. Edited by Richard Dutton. Oxford UP, 2009, pp. 136-50.

Bretz, Andrew. “Sung Silence: Complicity, Dramaturgy, and Song in Heywood’s Rape of Lucrece.” Early Theatre, vol. 19, no. 2, 2016, pp. 101-118.

Butler, Martin, Theatre and Crisis 1632-1642. Cambridge UP, 1984.

Coffin, Charlotte. "Burlesque or neoplatonic? Popular or elite? The shifting value of classical mythology in Love’s Mistress.” Interweaving Myths in Shakespeare and his Contemporaries. Edited by Janice Valls-Russell, Agnés Lafont and Charlotte Coffin. Manchester UP, 2017, pp. 216-238. 
Collins, Eleanor. Queen Henrietta Maria's Men and the Cockpit Repertory: Drama on the Drury Lane Stage, 1626-1636. Manchester UP. Forthcoming.

Connolly, Annalise. “Guy of Warwick, Godfrey of Bouillon, and Elizabethan Repertory.” Early Theatre vol. 12, no. 2, 2009, pp. 207-22.

Craig, Hugh, and Brett Greatley-Hirsch. Style, Computers, and Early Modern Drama: Beyond Authorship. Cambridge UP, 2017.

Davenant, William. The Just Italian. London, 1630.

Doebler, John, editor. The Knight of the Burning Pestle. Regents Drama Series. Arnold, 1967. Finkelpearl, Philip J. Court and Country Politics in the Plays of Beaumont and Fletcher. Oxford UP, 1990.

Ford, John. Love’s Sacrifice. London, 1633.

Griffith, Eva. A Jacobean Company and its Playhouse: The Queen's Servants at the Red Bull (c.1605-1619). Cambridge UP, 2013.

Gurr, Andrew, editor. The Knight of the Burning Pestle. Fountainwell Drama Texts, 1968. . The Shakespearean Stage, 1574-1642. Cambridge UP, 2009.

Harbage, Alfred. Annals of English Drama, 975-1700. Rev. Sam Schoenbaum. Methuen, 1964.

Hattaway, Michael, editor. The Knight of the Burning Pestle. New Mermaids. Methuen, 2002. Heywood, Thomas. Loves Maistresse: OR, The Queens Masque. London, 1636. . The Rape of Lucrece. London. 1609.

Hill, Tracey. “'The Grocers Honour’: or, Taking the City Seriously in The Knight of the Burning Pestle.” Early Theatre, vol. 20, no. 2, 2017, pp. 159-78.

Kinney, Clare R. “Undoing Romance: Beaumont and Fletcher’s Resistant Reading of The Countess of Pembroke's Arcadia.” Staging Early Modern Romance: Prose Fiction, 
Dramatic Romance and Shakespeare. Edited by Mary Ellen Lamb and Valerie Wayne. Routledge, 2009, pp. 203-18.

Leggatt, Alexander. “The Audience as Patron: The Knight of the Burning Pestle.”

Shakespeare and Theatrical Patronage in Early Modern England. Edited by Paul

Whitfield White and Suzanne R. Westfall. Cambridge UP, 2002, pp. 295-315.

Lesser, Zachary. Renaissance Drama and the Politics of Publication: Readings in the English Book Trade. Cambridge UP, 2004.

Lopez, Jeremy. Constructing the Canon of Early Modern Drama. Cambridge UP, 2014. Theatrical Convention and Audience Response in Early Modern Drama. Cambridge UP, 2003.

Loughnane, Rory. "Reputation and the Red Bull Theater, 1625-42.” The Yearbook of English Studies, vol. 44, 2014, pp. 29-50.

Lucas, Georgina. “Rape, Massacre, the Lucrece Tradition, and Alarum for London.” Early Theatre, vol. 20, no. 2, 2017, pp. 49-76.

Munro, Lucy. Children of the Queen's Revels: A Jacobean Theater Repertory. Cambridge UP, 2005. . "Governing the Pen to the Capacity of the Stage: Reading the Red Bull and Clerkenwell.” Early Theatre vol. 9, no. 2, 2006, pp. 130-14.

Price, Eoin. 'Public' and 'Private' Playhouses in Renaissance England: The Politics of Publication. Palgrave, 2015.

Publicover, Laurence. "Strangers at home: the Sherley brothers and dramatic romance." Renaissance Studies, vol. 24, no. 5, 2010, pp. 694-709.

Rowland, Richard. “(Gentle)men Behaving Badly: Aggression, Anxiety, and Repertory in the Playhouses of Early Modern London.” Medieval and Renaissance Drama in England vol. 25, 2012, pp. 17-41. 
. Thomas Heywood's Theatre, 1599-1639: Locations, Translations, and Conflict.

Ashgate, 2010.

Rutter, Joseph. The Shepheards Holy-Day. London. 1635.

Smith, Joshua S. "Reading Between the Acts: Satire and the Interludes in The Knight of the Burning Pestle.” Studies in Philology vol. 109, no. 4, 2012, pp. 474-95.

Steele, Mary Susan. Plays and Masques at Court During the Reigns of Elizabeth, James and Charles. Oxford UP, 1926.

Straznicky, Marta. “The Red Bull Repertory in Print.” Early Theatre, vol. 9, no. 2, 2006, pp. 144-56.

Teramura, Misha. “The Bold Beauchamps.” Lost Plays Database https://www.lostplays.org/index.php?title=Bold_Beauchamps. Accessed 27 Feb 2018.

Tosh, Will. Playing Indoors. Staging Early Modern Drama in the Sam Wanamaker Playhouse. Bloomsbury, 2018.

Webster, John. The White Divel. London, 1631.

West, William N. “Intertheatricality.” Early Modern Theatricality. Edited by Henry S. Turner, Oxford UP, 2013, pp. 151-72.

Whitted, Brent E. "Staging Exchange: Why The Knight of the Burning Pestle Flopped at Blackfriars in 1607.” Early Theatre, vol. 15, no. 2, 2012, pp. 111-30.

Wiggins, Martin, in association with Catherine Richardson. British Drama, 1533-1642: A Catalogue. Oxford UP. 2010-18.

Yearling, Rebecca. Ben Jonson, John Marston and Early Modern Drama: Satire and the Audience. Palgrave Macmillan, 2016.

Robert Zacharais. "Rafe’s Rebellion: Reconsidering The Knight of the Burning Pestle.” Renaissance and Reformation/Renaissance et Réforme, vol. 31, no. 3, 2003, pp. 10326. 
Zitner, Sheldon P, ed. The Knight of the Burning Pestle. Revels Series. Manchester UP, 2004.

Zucker, Adam. The Places of Wit in Early Modern English Comedy. Cambridge UP, 2011. 